\title{
Independent Directors, Moving Forward in Exercising Dominant Role: A Case of Malaysian Firms
}

\author{
Michael Tinggi ${ }^{1}$, Abu Hassan bin Md Isa ${ }^{1}$, Shaharudin Jakpar ${ }^{1}$, Sharifah Sabrina Syed Ali ${ }^{1} \&$ Salawati Sahari ${ }^{1}$ \\ ${ }^{1}$ Faculty of Economics and Business, University Malaysia Sarawak, Malaysia \\ Correspondence: Michael Tinggi, Department of Finance and Accounting, Faculty of Economics and Business, \\ University Malaysia Sarawak, Kota Samarahan, 94300, Sarawak, Malaysia. Tel: 60-3-584-443. E-mail: \\ tmichael@feb.unimas.my \\ Received: August 3, 2014 \\ Accepted: August 27, $2014 \quad$ Online Published: September 5, 2014 \\ doi:10.5430/ijba.v5n5p46 \\ URL: http://dx.doi.org/10.5430/ijba.v5n5p46
}

\begin{abstract}
Engaging independent directors at the board room is nothing new. The unexpected downfall of Enron and World Com in the 2000 has raised many eyebrows. Tasking internal and external auditors alone seems no longer sufficient to monitor firms' daily operating processes, procedural and reporting compliance and if not address may deteriorate firms performance. The independent directors' presence at the board level is increasingly and markedly felt. Many firms continue to move forward in order to make the audience of independent directors more meaningful. The findings from the board structure exploratory content analysis among an estimated panel of 381 Malaysian firms from 2001 to 2009, seems to suggest that increasing majority of independent directors at board room enable them to exercise a more dominant role towards profit orientation.
\end{abstract}

Keywords: dominant role, independent directors, profit orientation

\section{Introduction}

\subsection{Background}

The needs for the independent directors at the board room of public limited companies (plc) have raised many eyebrows. Interestingly we have observed more development on the appointment of independent directors' presence at board level. Surely there is much expectation that inviting these directors at the board-room is to bring about better and independent judgment to business decisions. Hopefully it may contribute to a more efficacious boards' deliberation and decision making process. An effective board may, among others bring about efficient audit committee which may influence quality financial reporting and statutory audit's work (Beasley et al., 2009; Cohen et al., 2004; Turley and Zaman, 2007 and Zaman et al., 2011). As oppose to full-time paid directors, the independent and non-executive directors are not compensated on fixed basis. Time spent with the company is constrained and privilege to information may be limited, thus making it more difficult for independent directors to exercise diligent judgment. The role is more or less acting as a monitoring agent at the board level particularly overseeing the activities of the organizational management and the auditing activities. Over the years the role of monitoring function in firms has been vested on the shoulder of both internal and external auditors. While the former focuses on internal control the latter emphasizes compliance in financial preparation and reporting. When so much money has been spent on the auditing fees, firms are now tasked with engaging independent directors to play another monitoring responsibility. This appointment is nonetheless come along not without cost.

Other rationale for appointing independent director is to perform the duty of its oversight role that is distinct from the management, impartial and being objective for the evaluation of the managerial performance of the organization's top executive. Even though, there is no legal requirement for statutory compliance, the codes of best practice of corporate governance recommend that at least some independent directors are required to be present in order to exercise independent judgment and are more likely to display indifference and without biasness in the decision-making process than the members of the top management, comprising the CEO and the other executive directors.

The outbreak of financial turmoil, such as the 1997's Asian financial crisis, has predominantly affecting countries such as Indonesia, Thailand, Philippines and South Korea. The weakness of their financial structures was badly 
exposed. The fallout exposed the loss from foreign cash injected into the equity portfolio and commercial bank loans of US\$12.1 and US\$55.5 billion into a minus US\$11.6 and negative US\$21.3 billion in 1997 respectively (Poon and Perry, 1999). The 2000 collapse of Enron reduced its corporation market value from US $\$ 90$ per share in 2000 to less than US\$1.00 in October 2001, representing a drop of 99 percent, and job losses directly and indirectly of 6,500 and 28,000 respectively with Andersen's US operation (Dugan and Spurgeon, 2002). The downfall of WorldCom led to massive job losses of 17,000 employees with its market value shrinking from US\$60 in 1999 to US\$2.00 per share in March 2002 (Brickey, 2003). The latest meltdown of the 2007/2008 subprime mortgage crisis in the United States revealed more disintegration in the financial structure, when it reported a negative growth of 23.72 percent in the fourth quarter of 2007 on US banking industry, and a forced liquidation of some US\$3.0 trillion in private label structured assets, depriving the US economy a vast amount of liquidity assets (Whalen, 2008). Confidence level on the stock and finance market reached a high time low. Indeed, in the aftermath, more financial shocks are yet to come if the weakness among financial structure is not addressed. It is even perceived that unresolved investors' confidence and unstable financial structure might have led to escalating ripple effects in many different parts of the world, particularly such as the current financial instability experienced in Greece, Portugal and Ireland in 2011.

Malaysia was not spared in the financial turmoil, resulting in the depletion of investors' and foreign currency managers' confidence and vast under-pricing in market capitalization. On 7 January 1998, it was reported that the value of ringgit to a dollar reached a lowest point of ringgit 4.88 from ringgit 2.57 in July 1997. The Bank Negara of Malaysia lost US $\$ 10$ billion trying to protect and shore up the value of Malaysian ringgit, and during the same period, two thirds of its stock market wealth which were previously accumulated from its six years worth of growth were completely wiped out (Poon and Perry, 1999). Against the backdrop of these financial meltdown, the government around the world including Malaysia rushed to introduce new legislation and laws in an attempt to improve level of corporate governance practice and to restore investors' confidence. Nevertheless any attempts to reform a firm may first begin from the top, which include the board members, who are typically bound by their fiduciary responsibilities in order to safeguard the interest of the shareholders and improving the well-being of the corporation.

The composition of the board to undertake the supervisory and the fiduciary role has not been uniform. The board is normally made up of both inside or executive and outside or independent directors. While inside directors are defined as those directors who also serve as officers of the firms (Byrd and Hickman, 1992; Hermalin and Weisbach, 1988 and Goodstein and Boeker, 1991), the outside or independent directors are being classified as non-management or non-executive members of the board (Daily and Dalton, 1992, 1993; Dalton and Kesner, 1987; Goodstein et al., 1994; Molz, 1988; Rosenstein et al., 1993; Schellenger, Wood and Tashaori, 1989).

The appropriateness of inside directors serving on board has been critically questioned as to their effectiveness as a monitoring figure at the upper level, especially the evaluation of the top management, such as the chief executive officer (CEO) of the organisation. Inherent in earlier studies by Baysinger and Hoskisson (1990) and Kesner and Dalton (1986), the inside directors may fear of being retaliated from treating the CEO harsly and this may possibly diminish their ability to provide an objective and meaningful monitoring and evaluation of the latter performance. Prior studies from Fleischer, Hazard and Klipper (1988) and Weisbach (1988), find inside directors being locked in an uncomfortable position in their role of evaluating the top management performance because of the conflicting objectives which sometimes can impede the role that the director assumes and in effect, may weaken the efficient discharge of responsibility expected from the inside directors.

The status of outside directors who are supposedly independent are reminded to bring about objectivity and clarity to the board in making decisions in an attempt to sustain the future survival and to cultivate growing prosperity of the organisation and silmutaneously championing the interest of the shareholders and the society at large (Malaysian Institute of Corporate Governance - MICG, 2003). Being independent and free from agency problem may provide independent directors the privilege to raise issues which may go beyond the profit-making concern of the organisation. Scarabotti (2009) suggests that boards are less likely to exercise efficient check and balance if they are composed of individuals who either maintain close ties to the management and believes that the independent status of directorships is particularly crucial in those areas where there is a potential for conflict of interest between managers and shareholders.

Outside directors who are supposed to be non-managing and independent are believed to be a more effective monitoring party, because their status of being independent may render them the privilege to be free from the CEO's influence and control (Johnson, Daily and Ellstrand, 1996). In contrast, this form of privilege may not be enjoyed by the executive directors whose role and the exercising of independence may be from time to time, are being controlled by the CEO's influence and authority. 
In view of the above, the appointment of independent or outside directors is regarded to have brought about more value added to the corporate board, in terms of impartiality, professionalism and effectiveness. While many firms are struggling with cutting down the operating costs, the appointment of independent directors is seen to have contradictorily added extra burden to the organizational financial belly. In other words it could have been seen to have exacerbated instead of ameliorating the agency costs, in addition to the financial obligations which arise from the existing engagement of external and internal auditors. While many organizations have speculated on the potential benefits to be derived from the deployment of independent directors, there is a simultaneous need to strike a balance between the number of independent directors the firm has to employ and the responsibility which is expected to be discharged from them, and the positive expectation that are to be realized from their engagement. The establishment of corporate governance among countries has made it almost statutory for all firms to have the presence of independent directors at board room as monitoring agent and in enhancing organizational custodianship. The corporation original objective has been steadfastly profit and shares' value maximization. Over the years, the management and the shareholders may have undertaken and built up a different philosophy and approach towards the organizational direction. While the management may like to see potential growth and development in terms of rewards and remunerations, the shareholders may take a different growth approach. Investors and shareholders may want returns in the form on an increase in the firm's market value, enhanced organizational size and quick payback. Eventually, the difference in these objectives could have been the cause for a possible gap in the corporate main objective, making it difficult to arrive at goal congruence for the benefit of both the management as well as shareholders of the organization. The independent directors' impartial audience is expected to be present may be expected to identify and address the gap and possibly bridging the gap in the corporate's objective.

The motivation behind this study is driven by first, the Agency Theory, which can be viewed as a nexus of contracts between different resource holders. Jensen and Meckling (1976) postulates that the segregation of principals (the shareholders) and the agents (the managers) has given rise to an agency problems and information asymmetry. There is a divergence of interest and purposes between managers and shareholders, and this diversity in aims is expected to be caused by a conflict of interest and information asymmetry between shareholders who have little or little access to information about the organization, in comparison to corporate managers who have the opportunity and incentive to manage the firm for their own self-interest. In a nutshell, managers would tend to behave and allocate the firms' resources in line with their own best interest, which is inconsistent with the shareholders objective, whose main aim is to maximize shareholders' wealth.

While agency costs have been expended in hiring internal and external auditors, the result has not been encouraging as firms continue to expose weakness in their financial structure. A stronger vigilant monitoring principal is required, thus independent directors are recommended.

Another motivation is the Resource dependence theory (Daily, Dalton \& Camella, 2003; Hillman et al, 2009) which addresses board members' contribution as boundary spanners of the organization and environment. It may comprise resourceful supply from independent directors who are expected to have acquired many years of business experience and skills and their collaborative advantage from outside which could be assimilated into the organization. In this role independent directors provide access to resources needed by the firm. To a greater extent, the independent directors who would mainly come from group of qualified and professional accountants and auditors may bring about greater credibility and attestation (Robertson and Davis, 1985), and may enhance further quality of reporting and information risk reduction, potentially benefitting the owner and the manager (Messier et al, 2007). This is supported by Normative Auditing Theory, which according to Robertson and Davis (1985), provide guidelines on the characteristic of the monitoring or auditing agents in order to achieve a normative result, indicating what good practice should be. The auditing theory provides standards to the professional skill, and the level of independence, which require directors to be unbiased and impartial in the discharge of their duty.

\subsection{Problem Statement}

Going back into the drawing board, each country is struggling with implementing on the right number of independent directors that may sit at the board room. There is no guiding principle that the composition of independent directors adopted for application by one country for each firm is better that the one applied in another country. When the independent directors are called upon to carry out the plans outlined in the code of corporate governance for each country, it is observed that there is no uniformity in the number of independent directors who have been deployed to carry out the role as monitoring and supervising agent. While some countries require their companies to have a minimum composition of independent directors of one third to total board, some countries raise the component to fifty percent, while some other countries are quite comfortable even with a smaller representation 
of its independent directors at the board room. It is observed that the United States and Australia make it a minimum requirement of 50 percent of independent or outside directors are represented in the board room. Notwithstanding the presence of other directors, at least they could take advantage of its simple majority to exercise the mandate vested in them.

In some countries, the application of 50 percent minimum requirement is more moderate, such as in India where the 50 percent minimum requirement is used when the chairman is an executive; in South Korea and United Kingdom, the 50 percent is applied for big firms or conglomerate. In some countries like Germany and Japan, the role of board of directors in corporate governance practice takes a different platform. In Japan a minimum of one independent director is sufficient, but when the firm is adopting a US-based three committee structure, at least two outside directors are required to be present. In West Germany a dual board structure is engaged. Nevertheless the majority of the countries portrayed in table 1, maintain a minimum of two independent directors or one third representation at the board level. Globally, there are three approaches to be adopted in the application of corporate governance practices, namely the prescriptive method, which requires companies to follow corporate governance code strictly; the non-prescriptive method, which allows companies to have a free hand in disclosing their actual practices and the hybrid method, allowing companies to vary the adoption of the corporate governance code according to the circumstances of their companies

In the Malaysian context, the Malaysian authorities have adopted the hybrid method, which will allow public limited companies (PLCs) to apply the principles of the Code of Corporate Governance voluntarily and to explain the extent of compliance with the Code of Corporate Governance best practices, a representation based governance is preferred with the objective of having independent directors to play a more active and intensive role over the management of the organization.

At the introductory stage, the researcher opines that in 2001 when the listing requirement made it almost compulsory to have independent directors representation at board level among all listed firms in Malaysia, many of the firms are contented with the minimum requirement set at either one third or minimum of two numbers, whichever is lower. At the micro level when the audit, nomination and remuneration committees are established, the listing requirement proposes that majority of the audit committee should come from independent directors but is silent on their representation in the remuneration and nomination committee.

The focus of the research has been trying to establish on the progress on the influence of independent directors adoption among firms in Malaysia since 2001 until 2009 both at board room and at committee level, most so at the audit committee level. The researcher opines that after several years of having independent directors both at board and audit level, certainly independent directors would have a lot to contribute towards profit orientation.

Independent directors who are recruited from pool of talented professionals, accountants and auditors may bring along with them experience and the four eyes capacity to spot strength and weakness, thus bringing about better performance towards profit orientation. What the research is trying to look at is, while independent directors bring along with them their expertise, diligence and professionalism and experiences, their role would still not be effective if their presence cannot be felt and enforced at the board room.

\subsection{Research Objectives}

In the light of the above some of the research objectives are developed;

(a)The main objective of the study is to determine if the independent directors' representation has brought about a dominant role towards profit orientation

(b)The research is conducted with a view to attain some specific objectives, which are as follows:

(i) To assess if engagement of independent directors tasking with all audit, nomination and remuneration bring about profit orientation;

(ii) To determine, when the independent directors whose dominant role is clearly defined can move the company towards profit orientation.

\section{Literature Review}

The domain upon which corporate governance and appointment of independent or outside directors have been based on, has received rising attention and has therefore provoked many interested parties to carry out a more in depth study of the role and contribution of the independent directors to firms. 
Kuala Lumpur Listing Requirement (KLSE) listing requirement as per Part A, 1.01, stipulates that a person qualified to be a director should be independent and terms of independence is supposed to be free of any business or any form of relationship which may interfere with the execution of independent judgment or may affect the ability to act in the best interest of the independent directors.

At the global stage independent director are defined as; in United states by the National Association of Corporate Directors Blue Ribbon Commission, 1996; In France defined by Vienot Report II, 1994; In United Kingdom, by Combined Code 1998; In Canada by Dey Report, 1994 and in Australia by Bosch Report, 1995 (MICG, 2003).

Past studies have discovered mixed evidence that independent directors do have contribution to organization either directly or indirectly, drawing upon the contribution of independent directors in order to fill the gap precipitated from agency problem, the positive accounting theory and the principal-principal agency theory.

The monitoring responsibility of the independent directors in the past has been measured against firms' performance and the repercussion on firms' performance find mixed evidence.

Studies preceding 1992 in the Unites States by Bhagat and Black, 2002; Hermalin and Weisbach, 1991) find that there is lack of correlation between board independent and corporate capitalization.

Baysinger \& Butler, (1985); Dennis and McConnell, (2003); Hermalin and Weisbach, (2003); De Andres, Azofra \& Lopez, 2005; Jackling \& Johl, (2009) and Giovannini, 2010 report inconsistent evidence of the influence of independent or outside directors on firm value.

On a more positive note, Choi, Park and Yoo (2007) for Korean firms and Dahya and McConnell (2007) for UK firms, both find strong evidence of positive effects of independent directors on market capitalization. Outside Directors can improve board effectiveness and firm performance (Weisbach, 1988; Anderson \& Reeb, 2004). Further cross sectional study of 12 Chinese banks from 2003 -2006 shows evidence that outside directors has positive impact on bank performance (Bai and Nam, 2009).

In a nut shell, contribution from independent directors shows mixed results, and therefore we are drawn to pose a question? Could the mixed results, be due to different deployment level of independent directors in many parts of the world. Perhaps the role and purpose of these directors could have been less effective because many firms prefer not to grant them a dominant role. Some companies which have recognized the value of increasing dominant role by independent directors may raise the representation of independent directors at board room and audit committee. Others may still adopt a passive approach, and therefore maintaining status quo. In other words there is no significant change in their representation.

\subsection{Board of Directors Characteristics}

Board of directors are the highest level of the firm's decision making process and therefore whatever is the decision made at this level, will be the final decision.

The Board is normally consisted of the chairman, the managing directors, and the rest of the directors. The board is divided further into two groups; first, the executive directors who are appointed on full time basis and the other are the non-executive independent directors. The latter, according to the listing requirement, must have at least a minimum of 2, or one third of the total board members, and at least one of them, will be competent and qualified. The listing requirement also requires the identification of the presence of senior independent directors and the role of the chief executive officer and the chairman.

\subsection{Audit, Nomination and Remuneration Committee}

The role of independent directors, are to serve in the audit, nomination and remuneration committee, of which the guidelines are stipulated in paragraph 15.10 of the Kuala Lumpur Listing Requirement (MICG, 2003)

\subsection{Audit Committee}

The code of corporate governance states that the audit committees should comprise minimum of three directors, a majority of whom are independent.

The audit committee objective is to reinforce a strong control culture with emphasis on upholding a sound system of internal control to safeguard shareholders' investment and the company's assets. An efficient audit committee helps to enhance the position of internal and external auditors in the continuous upgrading of the standards of financial reporting and auditing. Past study from Ravina and Sapienza, (2010) and Cook, Barbara and Wang (2011) report that audit committee membership of independent directors enhance firm's performance. 
To ensure accountability is at work during the process of auditing by the audit committee, the latter is expected to be independent. In addition, they are expected to discharge their responsibility competently. In view of this, the listing requirement recommended that the majority of the audit committee has accounting or finance qualification or work experience with one of them being a member of the Malaysian Institute of Accountants or has 3 years' working experience and is a member of accounting association or body. Serious attention is also dedicated to risk management, internal control and internal audit. The firms are recommended to disclose the process and framework used to assess the adequacy of the internal control systems and risk management. It is further recommended that the firm may also disclose whether the internal auditors of the firm has met or has exceeded the Internal Audit Standard (IIA Standards)

\subsection{Nomination Committee}

The code of corporate governance in Part 2 AA VIII, states that the committee should be made up wholly of independent directors. Even though there is a provision under section 128 of the Companies Act 1965, which governs the appointment and dismissal of directors f a public company by ordinary resolution.

The function of nomination committee is to nominate or re-nominate directors based on their contribution and performance and also to embark with responsibility of determining the factual independence of the company's independent directors.

Fich and White (2005) find that find that CEO who sits on the nomination committee affects board composition, has the likelihood of enhancing CEO's private interest, thereby impede the need for advancing the interest of the company's shareholders.

\subsection{Remuneration Committee}

The code requires that the composition of the committee should wholly or mainly comprising non-executive directors and the role is to determine the level of remunerations for executive directors, with a view to link remuneration rewards with directors' performance.

Independent directors in such a committee would be able be free of any prejudicial influence emanating from the management or an influential shareholder.

Previous study found that audit and compensation committee memberships enhance independent director trading performance on sales (Cook et al, 2011).

Building on the above underlying theory such as the Agency Theory, the Normative Auditing Theory and the Resource Dependent Theory, the adoption of the independent directors at board room and at the specified committee level are expected to assist organizations towards profit orientation.

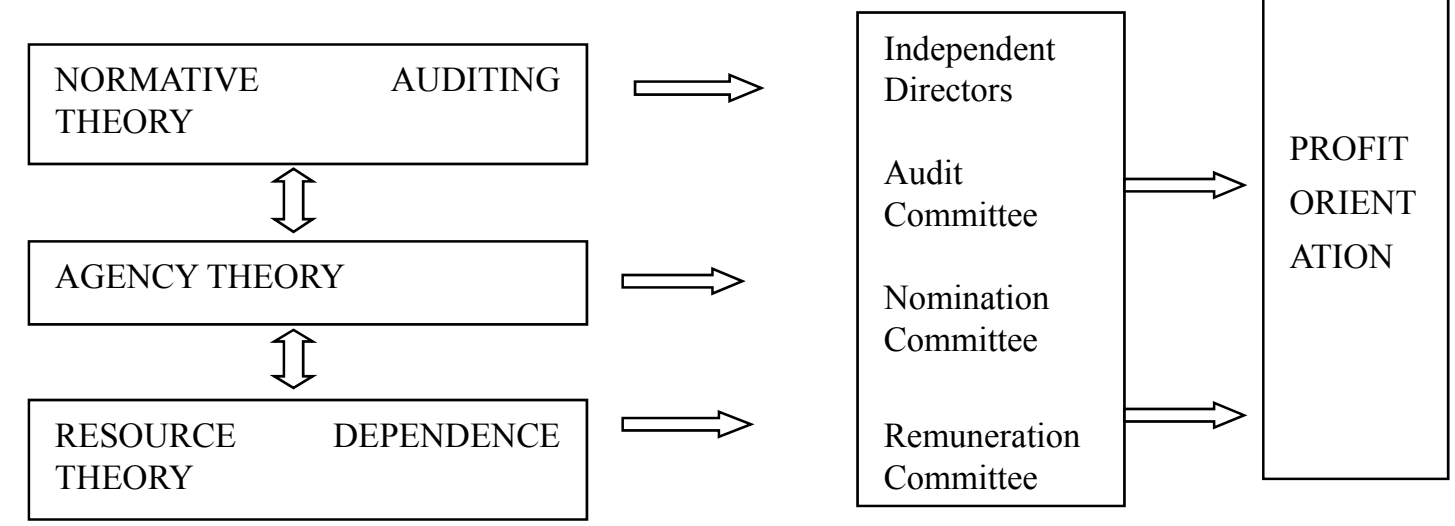

Figure 1. Conceptual framework

\subsection{Development of Research Hypothesis}

Independent directors are appointed so that they can play the role of monitoring and bridging the gap which has been caused by the conflicting objectives between shareholders and senior management of the firms. To be effective it has to be dominant and their voice can carry some weight in order to move the company towards profit orientation.

Thus, the first hypothesis is developed; 
H1: Independent directors whose voice are dominant and carry more weight can more the company effectively towards profit orientation.

At the micro level, the independent directors are also required to serve at the audit, remuneration and nomination committee. While the code of corporate governance 2001 (revised 2007 and 2012) requires the audit committee to be made up of the majority of independent directors, it is silent on both the remuneration and nomination committee, so much so that some companies do not even bother to fill up or form the nomination and the remuneration committee.

In the light of the above, three more hypotheses are developed.

H2: Firms with nomination committee in which dominant representation is not clearly defined assist to move the firms toward profit orientation.

H3: Firms with remuneration committee in which dominant representation is not clearly defined steer the firms towards firm's profit orientation.

H4: Firms with audit committee in which dominant representation is being more clearly defined are more effective at the board level towards organizational profit orientation.

\section{Research Methodology and Findings}

The data are collected from an estimated 381 Malaysian companies making up roughly 30 percent of the total companies listed in Kuala Lumpur Stock Exchange and it involves extraction of secondary data from all of the main sectors from 2001 to 2009. Data collection began with the selection of companies that were listed as early as 2000 and continue to be in existence at least after 2008. The final samples were finally reduced, due to some companies have already been suspended, merged or acquired and the profit and loss figures varies significantly. The data are collected from both between and within span of secondary panel of nine years. The linear panel equation is finally developed as:

lroait is a function of $\alpha+\beta 1$ indbdit $+\beta 2$ aubdit $+\beta 3$ nobdit $+\beta 4$ rmbdit + eit,

Where, lroait is return on assets for profit orientation, $\beta 1$ indbdit, a proxy for independent directors, aubdit is audit committee, $\beta 3$ nobdit is nomination committee and rmbdit, is remuneration committee and sit is the error term.

The three advanced panel method of analysis used to analyze the data are; First, the constant Co-efficient model, where lroait is a function of $\alpha+\beta 1$ indbdit $+\beta 2$ aubdit $+\beta 3$ nobdit $+\beta 4$ rmbdit + eit, :

Second, the Random Effect (RE) Model, where lroait is a function of $\alpha+\beta 1$ indbdit $+\beta 2$ aubdit $+\beta 3$ nobdit + $\beta 4 r m b d i t+\lambda i+U i t$, when $\varepsilon i t$ is decomposed into $\lambda i$ (individual or specific effect that has been excluded from the model and Uit ( the remainder disturbance); and

Third, is the Fixed Effect (FE) Model, where lroait is a function of $(\alpha+\lambda i)+\beta 1$ indbdit $+\beta 2$ aubdit $+\beta 3$ nobdit + $\beta 4 r m b d i t+$ Uit.

The choice of the three models was carried out by first, the Breusch and Pagan Lagrangian Multiplier (LM) Test,

$\frac{N T}{2(T-1)}\left[\frac{\sum_{i=1}^{N}\left(\sum_{t=1}^{T} \widehat{\Sigma} i t\right)^{2}}{\sum_{i=1}^{N} \sum_{t=1}^{T} \widehat{\Sigma}^{2} i t}-1\right]^{2}$ which has helped to discriminate between a random effects regression and a

simple OLS regression. The null hypothesis in the LM test is that variance across entities is zero, $H_{0}: \sigma_{\lambda}^{2}=0$ where the alternative hypothesis is $H_{1}: \sigma_{\lambda}^{2} \neq 0$.

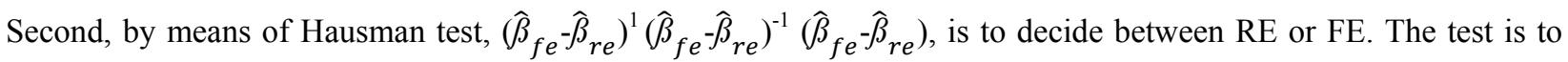
treat the country specific effects, whether they are correlated or uncorrelated with the regressors. The random effect estimator will deliver a consistent estimator that is efficient, otherwise it will be biased. Thus, there is a need to test for inefficiency as a result of the fixed effect estimator that has used only the within variation. In this case the hypothesis is developed;

The null hypothesis is $H_{0}: \operatorname{Cov}\left(\lambda_{i}, x_{i t}=0\right.$, where the alternative $H_{1}: \operatorname{Cov}\left(\lambda_{i}, x_{i t} \neq 0\right.$.

The analysis of data shall be classified by cluster as shown below: 
Table 1. Category of variables by cluster

\begin{tabular}{lll}
\hline Type of Cluster & Explanatory variables in cluster & Explained variable \\
\hline Cluster 1 & $\begin{array}{l}\text { Independent director, audit committee, nomination } \\
\text { committee and remuneration committee }\end{array}$ & ROA \\
\hline Cluster 2 & Independent director and nomination committee only & ROA \\
\hline Cluster 3 & Independent director and remuneration committee only & ROA \\
\hline Cluster 4 & Independent director and audit committee only & ROA \\
\hline
\end{tabular}

Table 2. Results of panel data on cluster 1

Dependent variables: ROA

\begin{tabular}{lccc}
\hline Regressor & Pooled OLS & Random Effect & Fixed Effect \\
\hline Constant & 1.821 & 1.41 & 1.375 \\
& $(12.88)^{* * *}$ & $(9.95)^{* * *}$ & $(9.43)^{* * *}$ \\
\hline Indbd & -1.046 & -0.224 & 0.118 \\
& $(-4.94)^{* * *}$ & $(-0.96)$ & $(0.45)$ \\
\hline Aubd & 0.143 & 0.088 & 0.061 \\
& $(0.83)$ & $(0.59)$ & $(0.40)$ \\
\hline Nobd & 0.389 & 0.163 & 0.036 \\
& $(2.98)^{* * *}$ & $(1.04)$ & $(0.20)$ \\
\hline Rmbd & -0.468 & -0.182 & -0.009 \\
& $(-4.06)^{* * *}$ & $(-1.29)$ & $(-0.06)$ \\
\hline Breusch and Pagan Lagrangian Multiplier & \multicolumn{2}{c}{$1016(0.000)^{* * *}$} & \\
(LM) & & & 2275 \\
\hline Hausman & 2275 & 2275 & \\
\hline Observations & & & \\
\hline
\end{tabular}

1. Figures in the parentheses are t-statistics, except for Breusch-Pagan LM test \& Hausman test which are p-values

2. ** and $* * *$ indicate the respective $5 \%$ and $1 \%$ significance level

When the process of discriminating among the three different models, constant co-efficient model, the RE model and the FE model was carried out, it was observed that both Breusch Pagan LM test in table 2(chi square value of 2016 or $\mathrm{p}=0.000<0.05$ ) has failed to accept the null hypothesis that $H_{0}: \sigma_{\lambda}^{2}=0$, suggesting that there is variance across entities, and Hausman tests in table 2 (chi square of 18.77 or $p=0.0009<0.05$ ) has failed to accept the null hypothesis that is $H_{0}$ : $\operatorname{Cov}\left(\lambda_{i}, x_{i t)}\right.$, suggesting that there is a serial correlation between firm specific effect and regressor term. The OLS pooled and RE models are both found to be inefficient.

Accepting FE model nevertheless does not seem to indicate that independent directors exercise dominant role towards profit orientation, therefore does not concur with the first hypothesis that independent directors voice are dominant so as to carry more weight towards profit orientation, thereby failed to accept the H1 hypothesis. It may seem to indicate that independent directors are seen to sit merely as board member just for the sake of fulfilling independent directors' representation at board room and board committee, perhaps suggesting that their role may not be effective after all. 
Table 3. Results of panel data on cluster 2

Dependent variable: ROA

\begin{tabular}{lccc}
\hline Regressor by Cluster & Pooled OLS & Random Effect & Fixed Effect \\
\hline Constant & 1.879 & 1.432 & 1.404 \\
& $(16.47)^{* * *}$ & $(11.03)^{* * *}$ & $(10.42)^{* * *}$ \\
\hline Indbd & -1.195 & -2.356 & 0.138 \\
& $(-6.03)^{* * *}$ & $(-1.11)$ & $(0.58)$ \\
\hline Nobd & 0.159 & 0.085 & 0.048 \\
& $(1.37)$ & $(0.61)$ & $(0.31)$ \\
\hline
\end{tabular}

Breusch and Pagan Lagrangian Multiplier $2070.06(0.000)^{* * *}$

\begin{tabular}{lllc}
\hline Hausman & \multicolumn{3}{c}{$14.23(0.0008)^{* * *}$} \\
\hline Observations & 2311 & 2311 & 2311
\end{tabular}

1. Figures in the parentheses are t-statistics, except for Breusch-Pagan LM test \& Hausman test which are p-values

2. $* *$ and $* * *$ indicate the respective $5 \%$ and $1 \%$ significance level

Table 4. Results of panel data on cluster 3

Dependent variable: ROA

\begin{tabular}{lccc}
\hline Regressor by Cluster & Pooled OLS & Random Effect & Fixed Effect \\
\hline Constant & 2.087 & 1.494 & 1.372 \\
& $(22.31)^{* * *}$ & $(13.72)^{* * *}$ & $(12.49)^{* * *}$ \\
\hline Indbd & -0.913 & -0.068 & 0.259 \\
& $(-4.58)^{* * *}$ & $(-0.32)$ & $(1.09)$ \\
\hline Rmbd & -0.317 & -0.101 & 0.025 \\
& $(-3.15)^{* * *}$ & $(-0.83)$ & $(0.18)$ \\
\hline
\end{tabular}

\begin{tabular}{lccc}
\hline Breusch and Pagan Lagrangian Multiplier & \multicolumn{2}{l}{$2055.72(0.000)^{* * *}$} \\
\hline Hausman & \multicolumn{4}{l}{$22.60(0.000)^{* * *}$} \\
\hline Observations & 2311 & 2311 & 2332
\end{tabular}

1. Figures in the parentheses are t-statistics, except for Breusch-Pagan LM test \& Hausman test which are p-values

2. ** and $* * *$ indicate the respective $5 \%$ and $1 \%$ significance level

Table 5. Results of panel data on cluster 4

Dependent variable: ROA

\begin{tabular}{lccc}
\hline Regressor by Cluster & Pooled OLS & Random Effect & Fixed Effect \\
\hline Constant & 1.763 & 1.354 & 1.305 \\
& $(15.83)^{* * *}$ & $(12.62)^{* * *}$ & $(12.46)^{* * *}$ \\
\hline Indbd & -0.898 & 0.182 & 0.611 \\
& $(-4.75)^{* * *}$ & $(0.89)$ & $(2.71)^{* * *}$ \\
\hline Aubd & 1.978 & 0.024 & -0.032 \\
& $(1.31)$ & $(0.19)$ & $(-0.23)$ \\
\hline Breusch and Pagan Lagrangian Multiplier & \multicolumn{2}{c}{$2397.25(0.000)^{* * *}$} \\
Hausman & \multicolumn{3}{c}{$21.96(0.000)^{* * *}$} \\
\hline Observations & 2748 & 2748 & 2748
\end{tabular}

1. Figures in the parentheses are t-statistics, except for Breusch-Pagan LM test \& Hausman test which are p-values

2. $* *$ and $* * *$ indicate the respective $5 \%$ and $1 \%$ significance level 
Extended regression pooled each board committee individually to the independent directors was carried out in sequence. First, table 3 pooled nomination committee to independent directors as cluster 1, where lroait is a function of $\alpha+\beta 1$ indbdit $+\beta 3$ nobdit $+\varepsilon i t$; ; second, Table 4 pooled remuneration committee to independent directors as cluster 2, where lroait is a function of $\alpha+\beta 1$ indbdit $+\beta 4 \mathrm{rmbdit}+$ eit, and; finally, Table 5 , is the pooling of audit committee to independent directors as cluster 3 , where lroait is a function of $\alpha+\beta 1$ indbdit $+\beta 2$ aubdit $+\varepsilon i t$.

Cluster 2 and 3 in Table 3 and Table 4 respectively seems to suggest that the FE model shows no significant influence of both nomination and remuneration committee on firms' profit orientation, thereby failed to accept hypothesis $\mathrm{H} 2$ and $\mathrm{H} 3$. It goes further to explain that it is quite consistent with the listing regulation, which is particularly silent on the specific component of independent directors under either the nomination or remuneration committee.

Cluster 4 in Table 5 pooled audit committee together with independent directors. Consistent with the listing requirement, a majority component of independent directors in the audit committee interestingly brings about positive results. The FE model reports that the independent directors who sit in the audit committee are able to report positively at the board room, therefore in effect may influence the rest of the board to behave in order to move the firm towards profit orientation. Table 5, shows the co-efficient value at 0.611 , significant at $\mathrm{z}$ value $=2.71$ or $\mathrm{p}$ $=0.000<0.05$, thereby fails to reject $\mathrm{H} 4$ that firms with audit committee in which dominant representation is being more clearly defined are more effective at the board level towards organizational profit orientation When all the committee and the board room independent directors are pooled together, the effectiveness with regards to their focus and commitment seems to have waned, when Table 2 reports all insignificant influence.

\section{Conclusion}

Independent directors have been the forefront of discussion among researchers especially in the current context of preserving good corporate governance and driving the firms towards profit orientation. This particular research dwells on the majority influence of independent directors either as a whole or performing a specific task for the company. While independent directors are required to serve at audit committee, nomination and remuneration committee, the listing regulation on the latter two is quite weak. Contrastingly, when the audit committee function is prioritized by being the majority at the audit board committee, they are able to exert dominant influence at the board room. Their influence could have been felt at the board room and thus may be able to influence the rest of the board room members to behave positively towards profit orientation. As for nomination and remuneration committee, consistent with no clear definition of independent directors' representation at the committee level, the influence of these directors seems insignificant and less dominant.

\section{Acknowledgement}

The author would like to extend its deepest gratitude and appreciation to the Ministry of Higher Education for the fundamental research grant which has been rendered for this research project vide FRGS/05 (33)/805/2011 (74).

\section{References}

Anderson, C.R., \& Reeb, M.D. (2004). Board composition: Balancing family influence in S\&P 500 firm. Administrative Science Quarterly, 49, 209-237

Bai, Y.S., \& Nam, D.W. (2009). An analysis of the impacts of corporate governance on the financial performance of the Chinese banks. International Journal of Revenue Management, 3(1), 102-118.

Baysinger, B.D., \& Butler, H. (1985). Corporate governance and the board of directors: Performance effects of changes in board composition. Journal of Law, Economics and Organizations, 1(1), 101-124.

Baysinger, B.D., \& Hoskisson, R.E. (1990). The composition of boards of directors and strategic control. Academy of Management Review, 15, 72-87.

Beasley, M.S., Carcello, J.V., Hermanson, D.R., \& Neal, T.L. (2009). The audit committee oversight process. Contemporary Accounting Research, 26(1), 65-122. http://dx.doi.org/10.1506/car.26.1.3

Berle, M., \& Means, G. (1932). The modern corporation and private property. New York: Macmillan.

Bhagat, S., \& Black, B. (2002). The non-correlation between board independence and long term firm performance. Journal of Corporate Law, 30, 232-273.

Brickey, K.F. (2003). From Enron to Worldcom and Beyond: Life and Crime after Sarbanes-Oxley. 81 Wash. ULQ.

Byrd, J.W., \& Hickman, K.A. (1992). Do outside directors monitor managers? Journal of Financial Economics, 32, 195-221. http://dx.doi.org/10.1016/0304-405X(92)90018-S 
Choi, J., Park, W., \& Yoo, S. (2007). The value of outside directors: Evidence from corporate governance reform in Korea. Journal of Financial and Quantitative Analysis, 42(4), 941-962. http://dx.doi.org/10.1017/S0022109000003458

Cohen, J., Krishnamoorthy, G., \& Wright, A. (2004). The corporate governance mosaic and financial reporting quality. Journal of Accounting Literature, 23, 87-148.

Cook, D.O, \& Barbara, Wang H.B. (2011). The informativeness and ability of independent multi-firm directors. Journal of Corporate Finance, 17, 108-121. http://dx.doi.org/10.1016/j.jcorpfin.2010.08.007

Dahya, J., \& McConnel, J. (2007). Board composition, corporate performance and the Cadbury Committee recommendation. Journal of Financial and Quantitative Analysis, 42, 535-564. http://dx.doi.org/10.1017/S0022109000004099

Daily, C.M., \& Dalton, D.R. (1992). The relationship between governance structure and corporate performance in entrepreneurial firms. Journal of Business Venturing, 7, 375-386. http://dx.doi.org/10.1016/0883-9026(92)90014-I

Daily, C.M., \& Dalton, D.R. (1993). Board of directors leadership and structure: Control and performance implications. Entrepreneurship Theory and Practice, 17(3), 65-81.

Daily, C.M., Dalton, D.R., \& Camella, Jr. A.A. (2003). The Governance: decades of dialogue and data. The Academy of Management Review, 28(3), 371-382.

Dalton, D.R., \& Kesner, I.F. (1987). Compositions and board duality in boards of directors: An international perspective. Journal of International Business $\quad$ Studies, $18, \quad 33-42$. http://dx.doi.org/10.1057/palgrave.jibs. 8490410

De Andreas, P., Azofra, V., \& Lopez, F. (2005). Corporate boards in OECD countries: Size, composition, functioning and effectiveness. Corporate Governance, 13(2), 197-210. http://dx.doi.org/10.1111/j.1467-8683.2005.00418.x

Dennis, D.K., \& McConnell, J.J. (2003). International corporate governance. Journal of Financial Quantitative Analysis, 38, 1-36. http://dx.doi.org/10.2307/4126762

Dugan, I.J., \& Spurgeon, D. (2002). Partners in peril: For most at Anderson Enron wasn't a client but now it is a problem. The Wall Street Journal, 21 March, C1.

Fich, E.M., \& White, L. (2005). Why do CEOs reciprocally sit on each other's boards? Journal of Corporate Finance, 11, 175-195. http://dx.doi.org/10.1016/j.jcorpfin.2003.06.002

Fleischer, A., Hazard, G.C., \& Klipper, M.A. (1988). Board games: The changing shape of corporate power. Boston, MA: Little, Brown.

Giovannini, R. (2010). Corporate governance, family ownership and performance. Journal of Management \& Governance, 14, 145-166. http://dx.doi.org/10.1007/s10997-009-9093-x

Goodstein, J., \& Boeker, W. (1991). Turbulence at the top: A new perspective on governance structure changes and strategic change. Academy of Management Journal, 34, 306-330. http://dx.doi.org/10.2307/256444

Goodstein, J., Gautam, K., \& Boeker, W. (1994). The effects of board size and diversity on strategic change. Strategic Management Journal, 15, 241-250. http://dx.doi.org/10.1002/smj.4250150305

Hermalin, B., \& Weisbach, M.S. (1991). The effects of board composition and direct incentives on firm performance. Financial Management, 20, 101-112. http://dx.doi.org/10.2307/3665716

Hermalin, B., \& Weisbach, M.S. (1998). The determinants of board composition. RAND Journal of Economics, 19, 589-606. http://dx.doi.org/10.2307/2555459

Hermalin, B., \& Weisbach, M.S. (2003). Boards of directors as an endogenously determined institution: a survey of the economic literature. Economic Policy Review, 9, 7-26.

Hillman, A.J, Withers, M.C., \& Collins, B.J. (2009). Resource Dependence Theory: A Review. Journal of Management, 5(6), 1404-1427. http://dx.doi.org/10.1177/0149206309343469

Jackling, B., \& Johl, S. (2009). Board structure and firm performance: Evidence from India's top companies. Corporate Governance: An International Review, 17(4), 492-509. http://dx.doi.org/10.1111/j.1467-8683.2009.00760.x 
Jensen, M., \& Meckling, W. (1976). Theory of firm: managerial behavior, agency costs and ownership structure. Journal of Financial Economics, 3(4), 305-360. http://dx.doi.org/10.1016/0304-405X(76)90026-X

Johnson, J.L., Daily, C.M., \& Ellsrand, A.E. (1996). Board of directors: A review of research agenda. Journal of Management, 22(3), 409-438. http://dx.doi.org/10.1177/014920639602200303

Kesner, I.F., \& Dalton, D.R. (1986). Board of directors and the checks and imbalances of corporate governance. Business Horizons, 29(5), 17-23. http://dx.doi.org/10.1016/0007-6813(86)90046-7

Malaysian Institute of Corporate Governance. (2003). Independent Directors, perceptions, roles and responsibilities. Kuala Lumpur: MICG.

Messier, W.F., Glover, S.M., Prawitt, D.F., \& Boh, M. (2007). Auditing and assurance services in Malaysia (3 ${ }^{\text {rd }}$ ed.). KL: McGrawHill Education.

Molz, R. (1988). Managerial domination of boards and financial performance. Journal of Business Research, 16, 235-249. http://dx.doi.org/10.1016/0148-2963(88)90072-0

Poon, J.P.H., \& Perry, M. (1999). The Asian economic "flu". A geography of crisis. The Professional Geographer, 51(2), 184-196. http://dx.doi.org/10.1111/0033-0124.00156

Ravina, E., \& Sapienza, P. (2010). What do independent directors know? Evidence from their trading. Review Financial Study, 23, 962-1003. http://dx.doi.org/10.1093/rfs/hhp027

Robertson, J.C., \& Davis, F.G. (1985). Auditing (4th ed.). Plano, Texas: Business Publication, Inc..

Rosenstein, J., Bruno, A.V., Bygrave, W.D., \& Taylor, N.T. (1993). The CEO, venture capitalists and the board. Journal of Business Venturing, 8, 99-113. http://dx.doi.org/10.1016/0883-9026(93)90014-V

Scarabotti, S. (2009). The independent directors' role in Europe: Developments and open debates in Italy. The Columbia Journal of European Law On-Line, 15, 77-82.

Schellenger, M.H., Wood, D.D., \& Tashakori, A. (1989). Board of director composition, shareholder wealth and dividend policy. Journal of Management, 15, 457-467. http://dx.doi.org/10.1177/014920638901500308

Turley, S., \& Zaman, M. (2004). Audit committee effectiveness: Information processes and behavioral effects. Accounting, Auditing and Accountability Journal, 20(4), 721-744.

Weisbach, M.S. (1988). Outside directors and CEO turnover. Journal of Financial Economics, 20, 431-460. http://dx.doi.org/10.1016/0304-405X(88)90053-0

Whalen, C. (2008). The Subprime Crisis: Cause, Effect and Consequences. Networks Financial Institute Policy Brief. Report No.: 2008-PB-04.

Zaman, M., Hudaid, M., \& Haniffa, R. (2011). Corporate governance quality, audit fees and non-audit fees. Journal of Business Finance and Accounting, 38(1-2), 165-197. http://dx.doi.org/10.1111/j.1468-5957.2010.02224.x 